\title{
Third parties' voices in a therapeutic interview
}

\author{
MICHĖLE GROSSEN and ANNE SALAZAR ORVIG
}

Abstract

Drawing on a dialogical approach inspired by Bakhtin, we start from the assumption that a concrete discussion is an intermingling between dialogue in praesentia and dialogue in absentia, and we refer to the notion of "enunciative positioning" to account for the various relations that a speaker may express toward the voices that he or she invokes. Our data are based on a first therapeutic interview between a therapist, a mother, and a child in a counseling center for children and adolescents. We identify the various voices invoked in this interview and show that three levels of discursive process were involved: (a) the speakers invoked absent speakers; (b) at the same time they developed their own discourse on the basis of their interlocutors' discourse which (c) itself drew on absent speakers or voices. We highlight the various discursive processes through which the speakers integrate their own voice into absent voices, or integrate a distant voice so that it loses its property of being a distant (and borrowed) voice. As a theoretical and methodological contribution to dialogism, our results show that absent voices and their specific intermingling with hic et nunc exchanges were a major resource for therapeutic processes.

Keywords: therapeutic interview; dialogism; enunciative positioning; voices; discourse analysis; heteroglossia.

\section{Introduction}

For a therapist, the first session of a therapeutic consultation ("a first interview") is a critical moment of the whole therapeutic process (Morrison 1993; Cyssau 1998). It is aimed at constructing a definition of the patient's "problem," and the patient's motivation in this process is essential in order to ensure 
his or her commitment to the therapy and to orient the therapist's actions. In the case of therapeutic consultation for adolescents and children, which is of interest here, the question of motivation is even more complex. In fact, even though the child is the patient, the parents are the therapist's principal interlocutors and the ones who have to make a decision about the continuation of a therapy. Moreover, in a consultation for children, the parents frequently consult at the request of a third party, typically the child's teacher (Cederborg 1997). Consequently, a therapist's central task is to assess whether the third party's request makes sense for the parents, what definition of the child's difficulties they give, and what are their own expectations.

From this standpoint, a first therapy session with a child and his or her parents is particularly suitable for analysis through a dialogical approach to language. In fact, according to Bakhtin's definition (1981, 1986), dialogue not only refers to interlocutory processes, but also to the fact that any discourse echoes the voices of other discourses that have been held elsewhere, or can be imagined. In line with Bakhtin's definition of dialogism, our work starts from the assumption that in every utterance there is a tension between the speaker's voice and others' voices, that of the interlocutors or third parties. This implies, first of all, that the participation framework (Goffman 1981) of any interaction, for example a therapy session, consists not only of actual participants, but also includes absent (or virtual) participants who play a role in the dynamics of discourse. Secondly, dialogism refers also to the fact that in every utterance there is a tension between these different voices, i.e., the speaker's voice and others' voices.

Drawing on a theoretical framework influenced by Bakhtin and other scholars working on a dialogical approach to language and cognition (François 1999; Marková 2003; Salazar Orvig 1999, 2005; Bres 2005; Marková et al. 2007; Linell 2009; Vion 1998), this article aims firstly to bring a theoretical and methodological contribution to dialogue analysis by showing how we can grasp the intermingling between, on the one hand, the present participants' dialogue in praesentia and, on the other hand, the dialogue in absentia with absent third parties whose discourse is invoked by the participants. Secondly, it aims to show how, in the case of a therapeutic interview, this intermingling contributes to a definition of the problem at the origin of the consultation. Our questions are therefore: How is it possible to identify the absent voices that are invoked in the participants' discourse? How do the participants invoke them and relate them with their own voices? How do they mobilize them for the construction and formulation of the problem?

We first introduce our theoretical framework and the basic notions that guided our method and then present the analysis of a first therapeutic session that concerned a child who had been referred by his teacher to a center of psychological consultation for children and adolescents. 


\section{Theoretical framework}

In this section, we focus on two points that are central for the understanding of our methodological approach: the notion of dialogue in Bakhtin's perspective and the notion of enunciative positioning.

\subsection{From dialogues in praesentia to dialogues in absentia in a therapeutic interview}

A "first" therapeutic interview can be defined as a social activity that brings together at least one therapist and his or her patient. In this activity, discourse is one of the means (most often, the principal means) through which the patient presents his or her difficulties (for the sake of brevity let us call it a "problem"). It is also through discourse that the therapist and the patient build up a certain representation, or definition of the problem, and sometimes formulate it explicitly (Gale 1991; Salazar Orvig 1995, 1998; Buttny 1996; Grossen and Apothéloz 1996; Grossen and Salazar Orvig 2006; Hak and De Boer 1996; Proia 1998; Antaki et al. 2005; Peräkylä et al. 2008). A therapeutic interview thus pertains to a certain genre (Grossen and Salazar Orvig 2006), that of professional or institutional discourse (Linell 2009; Sarangi and Roberts 1999; Mäkitalo and Säljö 2002). It is characterized by a fundamental asymmetry between the therapist and the patient(s), an asymmetry that is based, among other factors, on the participants' position with respect to what is said: while the patient talks about life events, feelings, thoughts, etc., that he or she has experienced, the therapist has to work on the client's report as he or she presents it. In the case of consultations for children, the therapist takes into account both the child's own reported experience and the parents' interpretation of the child's psychological state.

However, from a Bakhtinian point of view, the dialogical dimension of discourse refers to a fundamental property of discourse, that of being a socially and historically situated "living word" (Bakhtin 1981). According to this view, the dialogical dimension of discourse refers to the fact that any discourse is shaped by preceding discourses, as well as by the responses it anticipates. Consequently, a dialogue is not only a compositional structure of speech (what could be called "external dialogue"), but there is an internal dialogism, which is displayed within discourse itself: "Within the arena of almost every utterance an intense interaction and struggle between one's own and another's word is being waged, a process in which they oppose or dialogically interanimate each other" (1981: 354).

In a concrete discussion between two persons or more, this internal dialogism may be grasped at two different levels (François 2005; Salazar Orvig 2005): (a) the dialogue in praesentia, where various co-present participants 
talk together and link their own discourse to the other participants' discourse, take it up, reformulate it, reject it, etc.; (b) the dialogue in absentia, where each participant's discourse is made up of and through other discourses or voices, and enters into a sort of distant dialogue with absent third parties. More fundamentally, there is always an intermingling of the discourse of others within discourse:

$[\ldots]$ any utterance, when it is studied in greater depth under the concrete conditions of speech communication, revealed to us many half-concealed or completely concealed words of others with varying degrees of foreignness. Therefore, an utterance appears to be furrowed with distant and barely audible echoes of changes of speech subjects and dialogic overtones, greatly weakened utterance boundaries that are completely permeable to the author's expression. (Bakhtin 1986: 93)

From this standpoint, a concrete discussion is a dialogized intermingling between voices in praesentia and voices in absentia. In his analysis of discourse in the novel, Bakhtin referred to this constitutive phenomenon as heteroglossia, which he defined as

a special type of double-voiced discourse. It serves two speakers at the same time and expresses simultaneously two different intentions: the direct intention of the character who is speaking and the refracted intention of the author. (Bakhtin 1981: 324)

Bakhtin stressed both the heterogeneity of voices (genres, registers, styles, dialects, etc.) that constitute discourse and the fact that taking up or representing another's discourse necessarily implies a modification, a transformation, a confrontation, etc. In this intermingling, the speakers adopt various points of view on what is said by themselves or others.

\subsection{The speaker's enunciative positioning}

This conception of discourse has important consequences for the notion of "speaker" that we shall discuss by referring to research in French pragmatics, ${ }^{1}$ in particular with regard to the conception of discourse proposed by Ducrot and Anscombre (Anscombre and Ducrot 1983; Ducrot 1984). This conception is based on a distinction between speaker and enunciator, ${ }^{2}$ in which the enunciator refers to the point of view from which an utterance is produced. According to Haillet (2007: 42-43), this definition implies that any utterance represents at least one point of view (not to be confused with "opinion") or, put differently, has the property of presenting what is talked about from a certain angle or standpoint. For example, "John is sleeping" conveys a point of view, even though it does not say anything about the speaker's attitude toward what is represented in this utterance. In actual fact, there is no single point of view that could be a synthesis of all others (François 1994). 
However, in these studies, "polyphony" often seems to be defined as a monological phenomenon in which an isolated speaker puts forward different points of view. Now, as Rommetveit (1991) showed, putting viewpoints into words consists of building a dialogical construct that takes into consideration both what the addressee actually said and what he or she may answer. And among the enunciators represented in discourse, absent voices are intermingled with the addressee's voice. From Bakhtinian dialogism and Ducrot's notion of polyphony, it follows that the speaker always adopts some specific "enunciative positionings" with respect to the enunciators that he or she puts into words. Drawing on Vion (1998), we use the term "enunciative positioning" to refer to the relation that a speaker expresses toward the voices that he or she invokes, be they his or her own voices or those of other absent enunciators. ${ }^{3}$ This relation unfolds along two axes: (a) authorship: this refers to the fact that the speakers may or may not take epistemic responsibility for their discourse; that is, they may present what they say as their own production and take full responsibility for it. But they may also explicitly mention that it comes from elsewhere. Put differently, it regards the speakers' presentation of their words as being their own, or as coming from other voices; this presentation can be effected in different ways, ranging from an explicitly formulated rejection to an absence of any explicit responsibility for what is said: (b) alignment: this refers to the fact that a speaker may either adhere to an enunciation or distance him- or herself from it. Between these extremes, there are many subtle forms, such as hedges and mitigators, which may express the nature of the relationship between the speaker and the enunciator, including dialogue with one's own discourse. As a consequence, the participants in a discussion position themselves not only with respect to the other participants present, but also with respect to absent third parties.

Our general goal is therefore to illustrate the intermingling of present and absent voices by analyzing a therapeutic session where absent voices were particularly important and to show the role of these third parties' voices in the construction and formulation of the problem. We shall examine the participants' positioning toward the third parties' voices and analyze how the participants use these voices to orient the other participants' definitions and formulations of the problem.

\section{Presentation of the corpus, research questions, and method}

The interview analyzed in this article is taken from a larger corpus of initial sessions of therapeutic interviews that were collected in two public counseling services for children and adolescents in Switzerland. It lasted 56 minutes and brought together a mother, her seven-year old son, Alain, who attended the 
second grade of elementary school, and a woman therapist trained in systemic family therapy and with substantial work experience. The consultation was recommended by the child's teacher because of poor school achievement.

In this session, the child's participation was quite low (about $10 \%$ of the total number of utterances). ${ }^{4}$ This explains why none of the excerpts presented below includes the child's discourse. The child's interventions were mostly prompted by the therapist who questioned him about what had been said, or by the mother who used him as a witness. His participation pertained then to the same dialogical dynamics as those described below.

The interview, which was conducted in French, was audio recorded and transcribed using the transcription conventions (see Appendices 1 and 2).

In line with our theoretical framework, our research questions concerned the absent voices in the participants' discourse and the role of third parties in the construction of the problem.

\subsection{The voices of third parties}

Who were the participants or groups whose voices could be heard? More generally, whose voices were invoked within the participants' discourse? Before asking these questions, let us examine how, methodologically, voices may be identified.

3.1.1. Method. Voices of other enunciators may take on very different forms in discourse. They may be explicitly quoted but may also creep into an expression, or formulation, under a form that Bakhtin (1981) would have called "hybrid". Consequently, in the absence of any explicit marker, it is difficult to identify them or, on the contrary, to avoid considering that each piece of discourse is echoed by other voices and, hence, losing interest in the notion of voice. This is why, in our study, identification of the third parties' voices relied on three main criteria.

The first was formal and concerned cases in which the voices were discursively marked, as in the following excerpt:

(1) (T: therapist; A: Alain)

1 T 117: (to Alain) are you the only one' +

2 A 37: yeah

$3 \rightarrow$ T 118: only son as we say

In this extract, "we" in the metadiscursive clause "as we say" (line 3) does not refer to a concrete person but to a generic speaker (in French, it is indicated by the pronoun on, which frequently conveys a generic reference, as does the generic we in English). Other discursive markers characterize reported speech, 
the specificity of which is to indicate a direct reference to another's discourse, such as "he said," for example.

The second criterion relied on the discursive and semantic links that are constructed in and through dialogue:

1 T 245: (to Alain) [do you feel well when] you give orders

$2 \rightarrow \quad$ to mom' hmm' + and that you treat her like your

$3 \rightarrow \quad$ servant, hmm'

This extract comes after the mother reported that a doctor qualified her son as a "tyrant" (see Extract (16)). In this case, the utterance "you treat her like your servant" (lines 2 and 3 ) can be connected with the semantic field of previous quotations of the doctor's discourse (see also Extract (17)).

The third criterion refers to the analyst's knowledge of the cultural, social, and institutional background (such as scientific knowledge, commonsense knowledge, proverbs, rules or values, social representations, beliefs, stereotypes, etc.), which may be explicitly discussed or to which the participants may allude (for an example, see Extract (3) below).

Let us now examine whose voices were invoked in our interview.

3.1.2. The various types of voices. Our analysis showed that a great number of voices were evoked. For simplification, we grouped them according to four types, which should not, however, be taken as a rigid and definitive classification.

First, there were the voices of concrete persons or groups. They corresponded to the distant participants who were invoked by the mother and the child (for example, the father, the teacher, etc.). Among them, the teacher's voice was quoted 35 times and was so largely predominant that the teacher appeared to be an almost palpable (or audible) participant in the interview. Another voice, external to the family circle, was also mentioned, but less frequently (seven times): that of a doctor who, some years before, examined Alain for his allergies.

Then there were voices that corresponded to commonsense or supposedly shared social knowledge. In Extract (3) there is a generic utterance that refers to a gender stereotype concerning the differences between mothers and fathers:

(3)

1 M 192: (. .) fathers when they begin to scold, it is

2 always more frightening than mothers, $+(\ldots)$

Another type of voice was what could be called the voice of theory (Grossen 2006) and corresponded to cases where some elements of a scientific theory could be recognized in the participants' discourse: 
(4)

1 T 250: (laughs) (to Alain) or if they (his friends) tell

2 you nasty things it hurts you and you react very

3 strongly, hmm' you don't want to show that it hurts

4 you, so you react, +

From the therapist's explanation for Alain's relationships with his peers, we might retrieve a causal scheme belonging to psychology, i.e., being (or feeling) hurt might cause aggression.

Close to the voice of theory, there was also what could be called the voice of expertise. It was recognizable in assertions concerning topics pertaining to the psychologists' field of expertise:

1 T 194: I believe it's very important to make also a

2 difference between intellectual development hmm'

3 the knowledge he has err intelligence, but also

4 affective development [hmm']

We also found one example of reference to regulations or rules. It was recognizable, among other elements, by the use of a deontic verb (ought to):

1 M 92: (. . I I said now we first do homework, if you

2 have time we can see we can see and then if it's too

$3 \rightarrow \quad$ late gee it's too late, one ought to do it, one

$4 \rightarrow \quad$ ought (laughs) to do it

In lines 3 and 4, the mother reported her own discourse, which mentioned a rule that she recalled to her son, namely that homework had to be done.

The analysis showed an asymmetry in the type of voices that were invoked by the speakers: whereas the person's or group's voices, as well as the voice of commonsense or supposedly shared social knowledge were found both in the mother's and in the therapist's discourse, the voices of theory and expertise were found only in the therapist's discourse. These differences reflected the asymmetries of roles.

Moreover, a closer analysis of the interview showed that even though the teacher's voice was reported again and again, the doctor's voice, which was less pervasive, played an important role in the construction of the problem. This is why we shall now focus upon these two voices to answer our second research question. 


\subsection{The role of third parties' voices in the formulation of the problem}

Our question was twofold: What was the speakers' enunciative positioning with respect to the teacher's and doctor's voices? How did the participants invoke the teacher's and the doctor's voices in their formulation of the problem?

3.2.1. Method of analysis. Meta-discursive clauses referring to the speaker's discourse ("I declare that"), comments ("I know it") and hedges that concern the speaker's enunciation (for example "I am fully convinced that") were taken as clues of enunciative positioning. Drawing on Vion's (1998) work and adapting it for our own purpose, we identified four types of positioning:

(a) No positioning marker: The speaker's utterance did not explicitly represent an enunciator other than him- or herself. It took on a monological form and the inherent dialogism of discourse was concealed:

(7)

1 T 37: do you feel he has good contacts

2 with his mates'

$3 \rightarrow$ M 34: yes he has- he has- he has good contacts but (...)

(b) Difference: The speaker attributes the responsibility of an utterance (or part of an utterance) to another voice, without, however, expressing any evaluation of this enunciation, as in Extract (8):

(8)

1 T 143: + hmm but well it's the teacher who says so hmm'

2 who thinks that sometimes you get bored in class

The difference could also be expressed with respect to the speaker's own utterance, more frequently conveyed by different forms of hedges and mitigators (I think, maybe, etc.):

(c) Adhesion or agreement: the speaker expresses her adhesion with the voice she invoked:

(9)

1 M 22: (. . ) and she ((a friend of hers)) advised me to come

2 too, she told me that really it was it was good and

3 (...) actually that's what deci- decided me (...)

(d) Opposition: the speaker expresses her opposition to or disagreement with the voice she invoked. 
(10)

1 M 13: [well it's clear] she (the teacher) is the one who

2 told me about it (the consultation center) because

$3+$ I must say now it's better now

We examined the speakers' positioning when the teacher's and the doctor's voices were identified. We also examined at which moment of the interview the teacher's and doctor's voices were invoked and how the therapist and the mother used them to formulate the problem. Let us first see how the teacher's voice contributed to the formulation of the problem.

3.2.2. The teacher's voice in the construction of the problem. The teacher's was the first voice to be invoked at the very beginning of the session. It was then mostly invoked in the first half of the interview, that is, in the phase in which the mother presented her request to the therapist and the problem was formulated. More specifically, the teacher's voice could be identified when the mother talked about her son's difficulties. Extract (11) is very typical of this recurrent case:

$1 \quad$ T 37: do you feel he has good contacts

2 with his mates'

3 M 34: yes he has- he has- he has good contacts but

$4 \rightarrow \quad$ actually the teacher also told me that at school- he

5 gets on well,

6 T 38: hmm

$7 \quad$ M 35: he has good mates boys and also girls but actually he is

8 also quite brusque also in his- in his- in his

9 behaviors it's a::

The mother presented her son's problematic behavior (in this case, being "brusque", line 8) through the teacher's reported speech (lines 4-8). She did not give any clue as to her own enunciative positioning with respect to "being brusque," so that she just seemed to ventriloque the teacher's point of view.

There were, however, other instances in which the mother displayed her positioning toward the teacher's voice, as shown in Extract (12):

$1 \rightarrow$ M 61: no, it's ok, well it somewhat just happens + he is

$2 \rightarrow \quad$ bored, the teacher feels + that sometimes, she says

$3 \rightarrow \quad$ she says it's not that he cannot, we know it, I know

4 it also, if he wants to $=$

5 T 77: hmm 
$\begin{aligned} 6 \rightarrow \text { M 62: } & =\text { it works easily but }+ \text { we really feel that he's bored, } \\ & + \text { that he's not willing }\end{aligned}$

Here, the teacher's voice (echoed through reported speech) provided an explanation for the child's school failure ("it's not that he cannot [ . . ] if he wants to it works easily", lines 3-6). The mother displayed her alignment with the teacher's voice on three occasions: "we know" immediately rephrased into "I know" (line 3), which then explicitly asserted the mother's own point of view, and finally, "we really feel that" (line 6) in which she took up the first formulation ("he is bored", lines 1 and 2). Being "bored", which was first presented as the teacher's point of view, then included the mother's point of view, which was mingled with that of other speakers.

The same observation holds for the next extract:

\begin{tabular}{|c|c|c|}
\hline & M 110: & $\begin{array}{l}\text { there are things for example if there is an injustice } \\
\text { something which is really not fair he can get }\end{array}$ \\
\hline$\rightarrow$ & & himself into a state err he's very sensitive, the \\
\hline$\rightarrow$ & & ld me too by the way \\
\hline & T 77: & $\mathrm{hmm}$ \\
\hline$\rightarrow$ & M 111: & $\begin{array}{l}=\text { it's crazy how sensitive he is, what she tells me } \\
\text { too with respect to other children }+ \text { even actually he }\end{array}$ \\
\hline & & has- well she she what she thinks actually what she \\
\hline$\rightarrow$ & & $\begin{array}{l}\text { told me it's not that he's not able to, it's that he } \\
\text { doesn't want to }\end{array}$ \\
\hline
\end{tabular}

The mother brought a new element that categorized her son's attitude and was first formulated as a general description ("he's very sensitive", line 3). However, she completed her formulation with the teacher's voice ("the teacher told me too by the way", lines 3 and 4). The teacher's voice then reappeared twice, firstly as a repetition that stressed the previous formulation ("it's crazy how sensitive he is", line 6), secondly as a reformulation of her previous formulation in Extract (12) ("it's not that he's not able to, it's that he doesn't want to", lines 8 and 9).

As regards the therapist's discourse, the analysis showed that no instances similar to those described in the mother's discourse could be found. The therapist always invoked the teacher's voice by reformulating the mother's discourse, and her positioning toward the teacher's voice was either absent or slightly distant, as shown in Extract (14), which begins at the end of Extract (11):

1 M 34: (...) the teacher also told me (...)

$2 \rightarrow$ M 35: $(\ldots)$ he is quite brusque also in his- in his- in his

3 behaviors he's a:: 
$4 \quad$ T 39: [a direct]

5 M 36: [a little bit] excited, a bit direct yeah yeah +

$6 \rightarrow$ T 40: so he is brusque and then it provokes reactions'

$7 \quad$ M 37: from the others'

$8 \quad$ M 38: yeah (T looks at Alain)

$9 \rightarrow$ T 42: (to Alain) how do they react when you are brusque'

This excerpt provides a good illustration of the intermingling of the third parties' voice (here the teacher) and the participants' discourse. The term "brusque" was first borrowed from the teacher's discourse (line 2). Then, it was reintroduced by the therapist's reformulation of the mother's discourse ("so he is brusque and then it provokes reactions", line 6). The therapist integrated the teacher's voice into her own discourse without showing any enunciative positioning, submitting it to the mother's confirmation and, in so doing, implicitly asked the mother to position herself with respect to the teacher's voice. This reformulation therefore worked as a confrontation between the teacher's voice and the mother's point of view. Finally, the term "brusque" was used in addressing Alain as if it were the therapist's own lexical choice. The teacher's voice then completely faded away.

There were also other cases in which the therapist took up the teacher's voice and showed her own positioning toward the teacher's voice by distancing herself:

$\begin{array}{lll}1 & \text { TF 143: } & (\ldots)+(\text { to Alain) hmm but well it's the } \\ 2 & \rightarrow & \text { teacher who says so hmm' that she thinks } \\ 3 & & \text { sometimes you're bored in class hmm' is it true } \\ 4 & & \text { that sometimes you're bored in class }\end{array}$

5 A 41: no

6 T 144: what school subject do you like'

By addressing her question to the child, the therapist presented the teacher's point of view (as reported by the mother in Extract 12) to the child. In this case, however, she distanced herself from the teacher's voice: she first explicitly asserted that "it's the teacher who says so" (lines 1 and 2) and then she introduced her question to Alain by a modality "is it true that" (lines 3 and 4 ) which implied that she did not take responsibility for the teacher's reported point of view.

Let us now turn to what happened with the doctor's voice.

3.2.3. The doctor's voice in the formulation of the problem. The doctor's voice was not invoked until the second half of the interview (32nd minute). It was introduced by the mother: 
(16)

1 M 184: no he doesn't want to go to bed, he doesn't want to

be alone whereas + in principle we don't have any

3 problem but when he feels that now err'

$4 \rightarrow \quad$ I don't want to be alone he tyrannizes, that's the word

5 T 200: hmm

$6 \rightarrow$ M 185: he's a little tyrant, he was ill when he was little two

7 three years old I had him at the hospital, because

8 he had asthma + err not chronic, allergic $=$

9 TF 201: hmm

10 M 186: =to animal hair, dust and all sorts, I had him at three

$11 \rightarrow \quad$ at the hospital, the doctor told me + it won't go away

$12 \rightarrow \quad$ like this madam he tyrannizes you, he you: he already

$13 \rightarrow \quad$ sucked me at that time hmm' $=$

The mother introduced the word "tyrannizes" (line 4), which, in subsequent exchanges, became a key element in the formulation of the problem. She did it together with a metalinguistic comment ("that's the word", line 4) and a reformulation ("a little tyrant", line 6) that made it appear as though it were her own wording. However, this wording triggered off a story in which the mother attributed the origin of the expression "tyrannize" (line 12) to a doctor consulted some years previously. Let us note that the word "tyrant" echoes a frequent term in child psychology (e.g., Becker and Lescalier-Grosjean 2005). ${ }^{6}$

After introducing the expression "tyrannize," there was a hesitation in the mother's discourse ("he you:", line 12) that seemed to prepare the way for a second uptake of the doctor's discourse. However, she closed her turn by a reformulation of the doctor's voice ("he already sucked me", lines 12 and 13), which provoked a change in the enunciative positioning. In other words, the mother presented the description as her own formulation.

Later in the interview, only the therapist invoked to the doctor's voice. Consider the next extract:

1 M 205: (. .) when he was in first grade it seemed to me that I was just doing that, well I mean not with marks but I mean at the end of the day I reminded myself and I told myself but you just [bowled] $=$

\section{T 218: [bowl him out]}

M 206: =and gave him slaps' + and I said stop and now I

do it less' + practically never

T 219: so if I understand well you are nevertheless looking for

$9 \rightarrow \quad$ a mo- a way to help your son be less tyrannical

$10 \quad$ M 207: yeah 


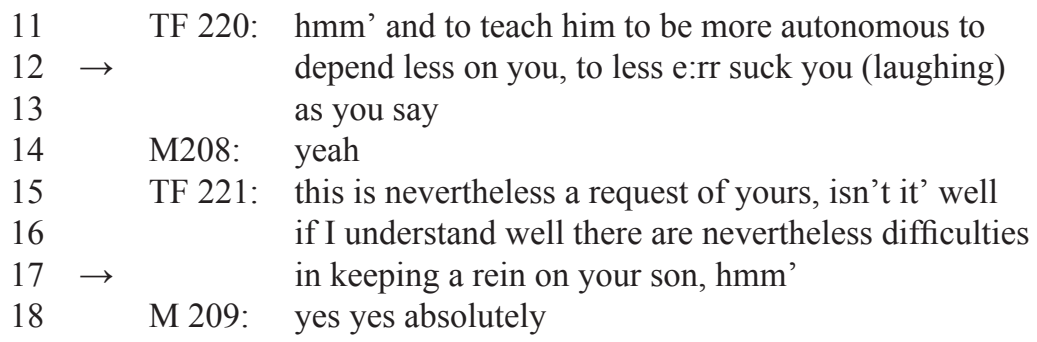

On line 9, the therapist reintroduced a variation of the term "tyrant" ("tyrannical") without any positioning marker, as if the term "tyrannize" had not been borrowed from the doctor's voice but was her own word, or a shared assumption. The word "tyrannical" appeared together with the formulation "suck you" (line 12) which was attributed to the mother ("as you say", line 13) and, therefore, marked a distance with the mother's wording. In line 16, the doctor's voice faded away but could still be heard in the therapist's use of the expression "to keep a rein on your son", which is, semantically, associated with the word "tyrant." By being completely mingled within the therapist's discourse, the doctor's voice then played the role of an ally in her formulation of the problem.

The next extract, which preceded the closing of the session, was the last time the doctor's voice was invoked:

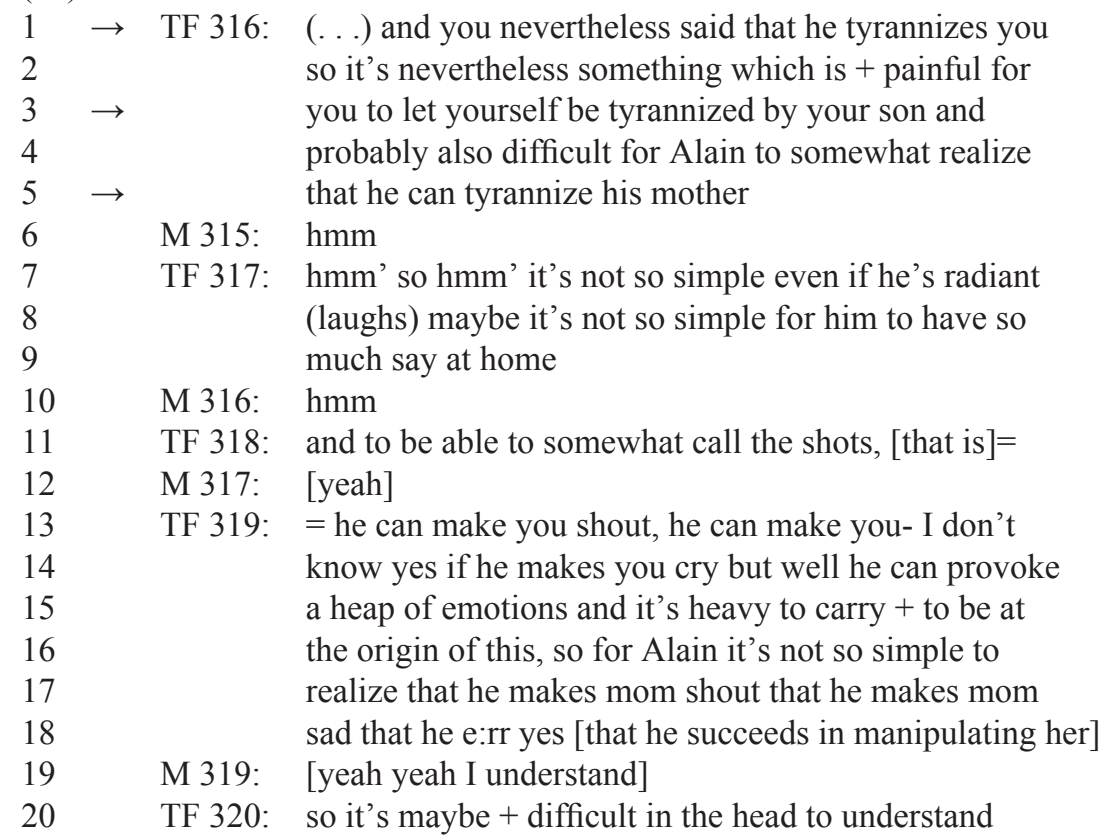


The doctor's voice could be identified on three occasions through the use of the word "tyrannize." On only the first occasion (line 1) did the therapist present the word "tyrannize" as a reformulation of the mother's discourse ("you nevertheless said", line 1) and confronted the mother with her formulation. By focusing on the problem as it had been supposedly described by the doctor, she removed the child's problem away from the school sphere, defined it as a problem experienced by the mother (and not by the teacher), and made it enter into her own field of competence. In none of these cases did she show her own enunciative positioning.

Her reformulation was then developed by an evaluation of the problem ("something which is painful", line 2), which took many forms: "not so simple" (lines 7, 8); "heavy to carry" (line 15), "difficult" (line 20), "not so comfortable" (line 24). All these expressions were mingled with other expressions belonging to the semantic field of "tyrant" ("call the shots", line 11; "make you cry", line 14; "can provoke a heap of emotions", lines 14, 15; "manipulating", line 18). In this move, the doctor's voice was completely integrated into the therapist's discourse and thus created a divergence with the mother's expectations. It led to a sort of insight ("yes I just never thought of that", line 25) that can be interpreted as a manifestation of the mother's new understanding of the problem. It also oriented the participants toward action, and, more specifically, to the next therapeutic session, as shown by the fact that immediately afterwards, the therapist suggested meeting both parents with the child and, as she put it, "leaving the teacher outside for the time being".

\section{Discussion and conclusion}

The aim of this article was twofold: firstly, to test the relevance and robustness of a dialogical approach by applying it to the analysis of a therapeutic interview, in which the voice of the patient (a child) was mostly silent and absent voices were very often invoked to discuss the child's difficulties; secondly, to show the significance of a dialogical approach in understanding the therapeutic processes, and, more specifically, to show how the intermingling between present and distant voices contributes to the construction of the patient's problem. The specificity of our work was to draw on a Bakhtinian dialogical approach to identify some discursive processes at work in a therapeutic interview 
and, hence, to use it for a broader purpose than the analysis of written texts, to which it is often limited.

Analysis of excerpts from one case study enabled us to observe in real time the processes through which voices intermingle to constitute a complex and heterogeneous discursive weave. This phenomenon, which has mostly been studied at a cultural level, originates in the hic et nunc exchanges taking place in dialogues in praesentia. Our analysis showed that three levels of discursive process were involved: (a) the speakers invoked absent speakers, whether explicitly or implicitly; (b) however, at the same time they developed their own discourse on the basis of their interlocutors' discourse; (c) the latter could itself draw on absent speakers or voices. We highlighted the various discursive processes through which speakers were not only able to integrate an absent voice into their own discourse, but also to merge their own voice into other voices. Conversely, we showed that a distant voice, which was integrated into the hic et nunc of the exchanges, could be taken up in the interlocutor's discourse, become an integral part of the dialogue in praesentia, and eventually lose its property of being a distant (and borrowed) voice.

In these complex discursive processes, it is not so much heteroglossia in itself that is interesting but rather dialogized heteroglossia (Bakhtin 1981; on this notion see also Morson and Emerson 1990), a notion that calls attention to two major points: firstly, by admitting that internal dialogism consists of a micro dialogue between one's own voice and other voices (Bres 2005), heteroglossia then not only refers to the borrowing of absent voices, but also to enunciation itself since, as we showed, a single speaker may adopt various enunciative positionings (Vion 1998) vis-à-vis the voices that are invoked. Hence, the problem is not simply to identify voices, but rather to examine how a speaker deals with them and what happens to them. Moreover we should bear in mind that an enunciative positioning is not an individual production but results from the constant interactive work carried out by the participants to link their discourse to that of their interlocutors, and to anticipate it. Secondly, these complex discursive processes also highlight the heterogeneity of the actual notion of speaker: the issue here is not only that various voices may be invoked in a same utterance, but also that the same utterance may converge with one voice and diverge with another.

As regards our second aim, our analysis showed that absent voices and their intermingling in the hic et nunc exchanges appear to be important resources for the construction of the child's problem. The mother used absent voices as a resource for presenting the problem from different standpoints, whereas the therapist referred to absent voices as a resource for introducing some divergences that prompted the mother to reconsider her own construction of the problem. Absent voices and their intermingling with hic et nunc exchanges led to various formulations of the problem and ended up with a formulation that 
focused more on the mother's than on the child's behavior. Thus, absent voices, and the way in which participants deal with them seem to be major resources for therapeutic changes. Our study is thus an invitation to focus our analyses of therapeutic interviews not only on "co-construction" processes between two supposedly homogeneous speakers, but to include absent voices in the participation framework and to show how they are invoked for the construction of the patient's problem. It is also an incentive to consider that the patient is not passively submitted to the therapist's interpretation, but plays a very active part in the construction of the problem.

Beyond these two aims, showing the complexity of the notion of speaker is another relevant contribution toward an understanding of therapeutic processes. In fact, in many studies on patient-therapist interactions (e.g., Grossen 2006; Peräkylä et al. 2008), the speaker is implicitly conceived of as a single and homogeneous voice that may, or may not, oppose the interlocutor's voice. The notion of enunciative positioning challenges this conception by showing that there are micro dialogues within a speaker's utterances. Consequently, the speaker appears to be fundamentally heterogeneous and dialogical. Many therapists could probably make sense of this result by drawing on one of the various theoretical models that, in the field of psychology and psychotherapy, point to the conflictual nature of the human mind. In other words, they would draw on what Peräkylä and Vehviläinen (2003: 730) called a "professional stock of interactional knowledge" (SIK), that is, an "organized knowledge (theories or conceptual models) concerning interaction, shared by particular practitioners or professionals." In line with Peräkylä and Vehviläinen's attempt to show how Conversation Analysis may document therapeutic practices, our results may then constitute a case in which dialogical discourse analysis "expands the description of practices provided by a SIK and suggests some of the missing links between the SIK and interactional practices" (2003: 732).

In summary, using a dialogical approach for the analysis of therapeutic interviews seems to open up a promising way both for the development of dialogism, and for an understanding of the discursive processes at work in therapeutic change.

\section{Appendix 1: Transcription conventions}

( ) Parentheses are used to give contextual information, such as laughter, telephone rings, sigh, etc.

An apostrophe indicates a rising intonation (not necessarily a question). A comma indicates a falling intonation.

$+\quad$ The sign + indicates a pause of 1 second. 
Colons represent elongated speech, a stretched sound.

$=\quad$ The equal sign indicates latched speech, when there is no gap between two turns.

A hyphen next to a word indicates that the speaker interrupts him- or herself or is interrupted by someone else.

\section{Appendix 2: The original extracts in French}

(1)

1 T 117: tu es tout seul'+

2 A 37: ouais

3 T 118: enfant unique comme on dit

(2)

1 T 245: [tu es bien quand] tu commandes

2 à maman' hein' + pis que tu la traites comme

3 ta servante, hein'

(3)

1 M 192: (. . ) les papas quand ils se mettent à gronder ça fait

2 toujours un peu plus peur que les mamans, $+(\ldots)$

(4)

1 T 250: (rire) (à A) ou si si s'ils te disent

2 des méchancetés ça te fait mal au coeur et tu réagis

3 très fort, hein' tu veux pas montrer que ça te fait

4 mal au coeur alors tu réagis, +

(5)

1 T 194: je crois que c'est très important de faire

2 la part des choses aussi entre le développement intellectuel

3 hein' les connaissances qu'il a euh l'intelligence, mais aussi

$4 \quad$ le développement affectif [hein']

(6)

1 M 92: (. . j'ai dit maintenant on fait d'abord les devoirs, si tu

2 as le temps on peut voir on peut voir et pis si c'est trop

3 tard ma foi c' est trop tard, il faut les faire, il faut

4 (rire) les faire (...) 
(7)

1 TF 76: bon j'ai eu de la peine pour les devoirs à la maison (...)

(8)

1 TF 143: + hmm mais enfin c'est la maîtresse qui dit ça hein'

2 qu'elle pense que tu $t^{\prime}$ ennuies quelquefois

3 en classe hein'

(9)

1 M 22: (. . .) pis elle m'a elle m'a conseillé de venir

2 aussi, elle m'a dit que vraiment c'était c'était bien et (. . .) en

3 fait c'est ce qui m'a déci- décidé (...)

1 M 13: [oui bon c'est clair ] c'est elle c'est elle qui m'en a parlé

2 parce que: + je dois dire maintenant

3 ça va mieux

1 T 37: vous avez l'impression qu'il a de bons contacts

2 avec ses copains'

3 M 34: oui il a des il a des il a des bons contacts mais

4

5

justement la la maîtresse m'a aussi dit qu'à l'éco- il

s'entend bien,

6 T 38: hmm

7 M 35: il a des des bons copains même des copines mais justement

il est assez brusque aussi dans son dans son dans ses comportements c'est un::

(12)

1 M 61: non ça va, bon ce qu'il y a un petit peu justement + ça

2 l'embête, la maîtresse a l'impression + que des fois elle elle dit

3 c'est pas qu'il peut pas, on le sait, moi aussi je le sais,

4 s'il veut $=$

5 T 77: hmm

6 M 62: =ça marche tout seul mais + on n'a vraiment l'impression que

7 ça l'embête, + qu'il a pas envie,

1 M 110: il y a des choses par exemple si: il lui arrive une injustice,

2 vraiment quelque chose qui est pas juste il peut se mettre

3 dans un état euh: il est très sensible, la maîtresse aussi 
6 M 111: c'est fou ce qu'il est sensible, ce qu' elle me dit

7
aussi par rapport aux autres enfants + même justement il a- bon elle elle ce qu'elle pense en fait ce qu'elle $m^{\prime}$ a dit $c^{\prime}$ est pas qu'il arrive pas, $c^{\prime}$ est qu'il veut pas

1 M 34: (. .) la maîtresse m'a aussi dit (. . .)

2 M 35: (. .) il est assez brusque aussi dans son dans son dans ses comportements c'est un::

3 T 39: [un direct]

4 M 36: [petit peu] un exalté, un direct ouais ouais +

5 T 40: alors il est brusque et puis ça provoque des réactions'

6 M 37: ouais

7 T 41: de la part des autres'

8 M 38: ouais (T se tourne vers A)

9 T 42: (se tourne vers A) comment ils réagissent quand tu es brusque'

1 T 143: (..)+ (se tourne vers A) hmm mais enfin c'est

2 la maîtresse qui dit ça hein' qu'elle pense que

3 tu t'ennuies quelquefois en classe hein' $c^{\prime}$ est vrai que

4 tu t'ennuies quelquefois en classe'

5 A 41: non

6 T 144: qu'est -ce que tu aimes bien comme branche'

1 M 184: non il veut pas aller au lit, il veut pas

2 rester tout seul alors que + en principe on n'a pas

3 de problème mais quand il a l'impression maintenant euh

$4 \quad$ j'ai pas envie d'être tout seul il tyrannise, voilà le mot

5 T 200: hmm

6 M 185: c'est un petit tyran, il a il a été malade quand il était petit deux

7 trois ans je l'ai eu à l'hôpital, parce qu'il

8 a de $1^{\prime}$ asthme + euh pas chronique, allergique $=$

9 T 201: hmm

10 M 186: =aux poils d'animaux, poussières et toute sorte, je l'ai eu à trois ans à l'hôpital le médecin il m'a dit + ça veut ça veut pas aller comme ça madame il vous tyrannise il vous: il me suçait déjà à l'époque hein'= 
(17)

1 M 205: (. . .) quand il était en première où il me semblait que

11 T 318: et de pouvoir faire d'une certaine manière la pluie ou le beau temps, [c'est-à -dire $]=$

12 M 317: [ouais]

13 T 319: =il peut vous faire crier, il peut vous faire - je sais pas

20 T 320: alors c'est peut -être + difficile dans la tête de comprendre 


\section{Michèle Grossen and Anne Salazar Orvig}

21

22 M 319: [hmm]

23 T 321: donc euh il me semble que sa position + là où il se

$24 \quad$ trouve est est pas si confortable pour lui, donc euh [et moi]

25 M 320: [oui justement $\mathrm{j}$ 'avais jamais] j'avais jamais pensé à ça

\section{Notes}

1. This theoretical framework has interesting correspondences with Goffman's (1981) approach and with the contemporary approach inspired by his work.

2. Let us note that Ducrot made more distinctions than the one between speaker and enunciator. However, for our present purpose, these further distinctions are not necessary.

3. The notion of enunciative positioning should not be confused either with other uses of the term "positioning," for example the construction of roles in actual interactions (asymmetrical relationships, etc.), especially in terms of agreement/disagreement, arguing, opposition, etc., or with the interactional implications of the expression of subjectivity in a dialogue.

4. A low participation is quite typical with children of this age (Aronsson and Cederborg 1994; Cederborg 1997; Grossen and Diemand Rollet 2003).

5. A research on Google combining the words child, tyrant, and psychology was made on 19 September 2009 and resulted in 54,800 occurrences.

\section{References}

Anscombre, J.-C. \& O. Ducrot. 1983. L'argumentation dans la langue. Bruxelles: Mardaga.

Antaki, C., R. Barnes \& I. Leudar. 2005. Diagnostic formulations in psychotherapy. Discourse Studies 7(6). 627-647.

Aronsson, K. \& A.-C. Cederborg. 1994. Conarration and voice in family therapy: Voicing, devoicing and orchestration. Text 14. 345-370.

Bakhtin, M. 1981. The dialogic imagination: Four essays by M. M. Bakhtine. Austin, TX: University of Texas Press.

Bakhtin, M. 1986. Speech genre and other late essays. Austin, TX: University of Texas Press.

Becker, E. de \& I. Lescalier-Grosjean. 2005. La «famille-enfant-roi» et la thérapie familiale. Cahiers Critiques de Thérapie Familiale et de Pratiques de Réseaux, 34(1). 13-34.

Bres, J. 2005. Savoir de quoi on parle: dialogue, dialogal, dialogique; dialogisme, polyphonie. In J. Bres, P. P. Haillet, S. Mellet, H. Nølke \& L. Rosier (eds.), Dialogisme et polyphonie. Approches linguistiques, 47-61. Brussels: De Boek Duculot.

Buttny, R. 1996. Clients' and therapist's joint construction of the clients' problems. Research on Language and Social Interaction 29(2). 125-153.

Cederborg, A.-C. 1997. Young children's participation in family talk. The American Journal of Family Therapy 25(1). 28-38.

Cyssau, C. 1998. L'entretien en clinique. Paris: In Press.

Ducrot, O. 1984. Le dire et le dit. Paris: Minuit.

François, F. 1994. Morale et mise en mots. Paris: L'Harmattan.

François, F. 1999. Le discours et ses entours. Essai sur l'interprétation. Paris: L'Harmattan.

François, F. 2005. Interprétation et dialogue chez des enfants et quelques autres. Lyon: ENS. 
Gale, J. E. 1991. Conversation analysis in therapeutic discourse: Pursuit of a therapeutic agenda. Norwood, NJ: Ablex.

Goffman, I. 1981. Forms of talk. Philadelphia: University of Pennsylvania Press.

Grossen, M. 2006. Analyse de la demande et « construction du problème » dans un premier entretien. In L'entretien clinique en pratiques. Analyse des interactions verbales d'un genre hétérogène, M. Grossen \& A. Salazar Orvig (eds.), 129-148. Paris: Belin.

Grossen, M. \& D. Apothéloz. 1996. Communicating about communication in a therapeutic interview. Journal of Language and Social Psychology 15(2). 101-132.

Grossen, M. \& S. Diemand Rollet. 2003. La prise de parole de l'enfant dans des entretiens cliniques: Les effets pragmatiques des changements de cadre participatif provoqués par un adulte. Psychologie de l'Interaction 15/16. 153-193.

Grossen, M. \& A. Salazar Orvig. 2006. L'entretien clinique en pratiques. Analyse des interactions verbales d'un genre hétérogène. Paris: Belin.

Haillet, P. P. 2007. Pour une linguistique des représentations discursives. Brussels: De Boeck.

Hak, T. \& F. De Boer. 1996. Formulations in first encounters. Journal of Pragmatics 25(1). 83-99.

Linell, P. 2009. Rethinking language, mind, and world dialogically. Charlotte, NC: Information Age.

Mäkitalo, A. \& R. Säljö. 2002. Talk in institutional context and institutional context in talk: Categories as situated practices. Text 22(1). 57-82.

Marková, I. 2003. Dialogicality and social representations. The dynamics of mind. Cambridge: Cambridge University Press.

Marková, I., P. Linell, M. Grossen \& A. Salazar Orvig. 2007. Dialogue in focus groups: Exploring socially shared knowledge. London: Equinox.

Morrison, J. 1993. The first interview. A guide for clinicians. New York: The Guilford Press.

Morson, G. S. \& C. Emerson. 1990. Mikhaïl Bakhtin. Creation of a prosaics. Stanford, CA: Stanford University Press.

Peräkylä, A. \& S. Vehviläinen. 2003. Conversation analysis and the professional stocks of interactional knowledge. Discourse and Society 14(6). 727-750.

Peräkylä, A., C. Antaki, S. Vehviläinen \& I. Leudar. 2008. Conversation analysis and psychotherapy. Cambridge, MA: Cambridge University Press.

Proia, N. 1998. Analysis of a first therapy interview: Objectives and methods. Pragmatics 8(2). 185-202.

Rommetveit, R. 1991. On epistemic responsibility in human communication. In H. Rönning \& K. Lundby (eds.), Media and communication. Readings in methodology, history and culture, 13-27. Oslo: Norwegian University Press.

Salazar Orvig, A. 1995. Misunderstandings and the construction of dialogue in a clinical interview. International Journal of Applied Psycholinguistics 11(31). 227-247.

Salazar Orvig, A. 1998. Interpreting and diverging in clinical interviews. Pragmatics 8(2). $167-$ 184.

Salazar Orvig, A. 1999. Les mouvements du discours. Paris: L'Harmattan.

Salazar Orvig, A. 2005. Les facettes du dialogisme dans une discussion ordinaire. In P. Haillet \& G. Karmaoui (eds.), Regards sur l'héritage de Mikhaïl Bakhtine, 35-66. Amiens: Encrage.

Sarangi, S. \& C. Roberts (eds.). 1999. Talk, work and institutional order: Discourse in medical, mediation and management settings. Berlin \& New York: Mouton de Gruyter.

Vion, R. 1998. De l'instabilité des positionnements énonciatifs dans le discours. In J. Verschuern (ed.), Pragmatics in 1998: Selected papers from the 6th International Pragmatics Conference, 577-589. Antwerp: International Pragmatics Association.

Michèle Grossen is Professor of Social Psychology at the University of Lausanne (Switzerland). Her research interests include social interaction in learning and the analysis of verbal interactions 


\section{Michèle Grossen and Anne Salazar Orvig}

in clinical interviews. She is co-editor with Anne Salazar Orvig of L'entretien clinique en pratiques: analyse des interactions verbales d'un genre hétérogène (Belin, 2006). Address for correspondence: Michèle Grossen, University of Lausanne, Faculty of Political and Social Sciences, Anthropole, CH-1015 Lausanne, Switzerland <Michele.grossen@unil.ch>.

Anne Salazar Orvig is Professor of Linguistics at the University Sorbonne Nouvelle. Her work concerns a dialogical approach of dialogue analysis both in the development of the young child and in clinical interviews. She is co-author (with Michèle Grossen, Ivana Marková, and Per Linell) of Dialogue in Focus Groups: Exploring Socially Shared Knowledge (Equinox, 2007). Address for correspondence: Anne Salazar Orvig, University Sorbonne Nouvelle-ILPGA, 19, rue des Bernardins, 75005 Paris, France < anne.salazar-orvig@univ-paris3.fr>. 